\title{
Requires Secure Email Delivery of XML Indicator
}

National Cancer Institute

\section{Source}

National Cancer Institute. Requires Secure Email Delivery of XML Indicator. NCI

Thesaurus. Code C127799.

An indication as to whether the XML copy of the CT application requires secure E-mail delivery. 